Article

\title{
Fluorescent Thienothiophene-Containing Squaraine Dyes and Threaded Supramolecular Complexes with Tunable Wavelengths between 600-800 nm
}

\author{
Wenqi Liu ${ }^{\mathbb{D}}$, Hannah H. McGarraugh ${ }^{(\mathbb{D})}$ and Bradley D. Smith * (D) \\ Department of Chemistry and Biochemistry, 236 Nieuwland Science Hall, University of Notre Dame, \\ Notre Dame, IN 46556, USA; wenqi.liu@northwestern.edu (W.L.); hmcgarra@nd.edu (H.H.M.) \\ * Correspondence: smith.115@nd.edu; Tel.: +1-574-631-8632
}

Academic Editor: Maged Henary

Received: 15 August 2018; Accepted: 31 August 2018; Published: 1 September 2018

\begin{abstract}
A new family of fluorescent thiophene and thienothiophene-containing squaraine dyes is described with tunable wavelengths that cover the absorption/emission range of 600-800 nm. The deep-red and near-infrared fluorescent compounds were easily prepared by simple synthesis and purification methods. Spectral studies showed that each squaraine was rapidly encapsulated by a tetralactam macrocycle, with nanomolar affinity in water, to produce a threaded supramolecular complex with high chemical stability, increased fluorescence quantum yield, and decreased fluorescence quenching upon dye self-aggregation. Energy transfer within the supramolecular complex permitted multiplex emission. That is, two separate dyes with fluorescence emission bands that match the popular Cy5 and Cy7 channels, could be simultaneously excited with a beam of $375 \mathrm{~nm}$ light. A broad range of practical applications is envisioned in healthcare diagnostics, microscopy, molecular imaging, and fluorescence-guided surgery.
\end{abstract}

Keywords: near infrared dye; fluorescence; supramolecular recognition; non-covalent; host guest; synthesis; quantum yield; multiplex imaging

\section{Introduction}

Organic dyes that emit fluorescence in the near infrared (NIR) window (650-900 nm) are needed for biological imaging as this wavelength region has relatively deep tissue penetration, minimal tissue auto fluorescence, and lower Rayleigh scattering of the light [1-3]. At present, many NIR fluorescent probes are based on cyanine dyes because of their large molar absorption coefficients, moderate to high fluorescence quantum yields, and broad wavelength tunability [4]. Although the practical value and utility of cyanine dyes in biological studies is without doubt, they can exhibit some non-optimal molecular properties such as poor chemical and photostability, limited water solubility, propensity to self-quench upon dye aggregation, and difficult purifications due to the ionic molecular structures [5]. Thus, an ongoing task for dye chemists is to prepare new classes of NIR fluorescent dyes for biological imaging applications.

Squaraine dyes are a well-known family of NIR fluorescent dyes with intense and narrow absorption bands, high fluorescence quantum yields, and excellent photostabilities [6]. Because of these attractive optical properties, squaraines have been investigated over the years for many potential applications [7-11]. In the specific case of biological imaging, the development of squaraine dyes as NIR fluorescent probes has been limited by technical challenges such as poor chemical stability in biological media and a propensity for dye self-aggregation [12]. Our research group has discovered that both problems can be abrogated by encapsulation of the dye inside a protective 
macrocycle [13]. The equilibrium in Scheme 1 shows complexation of an bis(aminothiophene)squaraine dye by a tetralactam macrocycle that has two anthracene sidewalls. The threaded complex is stabilized by a synergistic combination of aromatic stacking and hydrogen bonding interactions between the two supramolecular components, and complexation produces a red-shift of the squaraine absorption/emission maxima [14]. Moreover, the surrounding macrocycle protects the encapsulated squaraine dye from nucleophilic attack, attenuates the quenching effects caused by dye self-aggregation, and enhances the squaraine quantum yield in water [14-17]. The favorable fluorescence properties of these threaded squaraine macrocycle complexes have been exploited for different applications in biological imaging [18,19], diagnostics [20] and liposome surface functionalization [21]. Most squaraine dyes and squaraine/macrocycle complexes (including the system in Scheme 1) have fluorescence emission bands in a narrow region between $650-700 \mathrm{~nm}$, which makes them useful substitutes for the common cyanine dye, Cy-5, in many types of microscopy and in vivo imaging techniques $[3,18]$. Looking to the future, there is little doubt that the value of squaraine dyes for biological imaging would be enhanced if additional dye structures could be produced with absorption/emission wavelengths that cover a broader window and extend up to $850 \mathrm{~nm}$. Even more utility would be gained if the squaraine structures allowed macrocycle threading to produce high stability complexes. Within the literature on squaraine dyes is a small and scattered collection of structures with squaraine absorption/emission bands that are close to $800 \mathrm{~nm}$ [22-26]. None of these were considered suitable for our needs because the structures were either too hard to prepare as water-soluble molecules or they contained sterically large terminal groups that would prevent macrocycle threading.

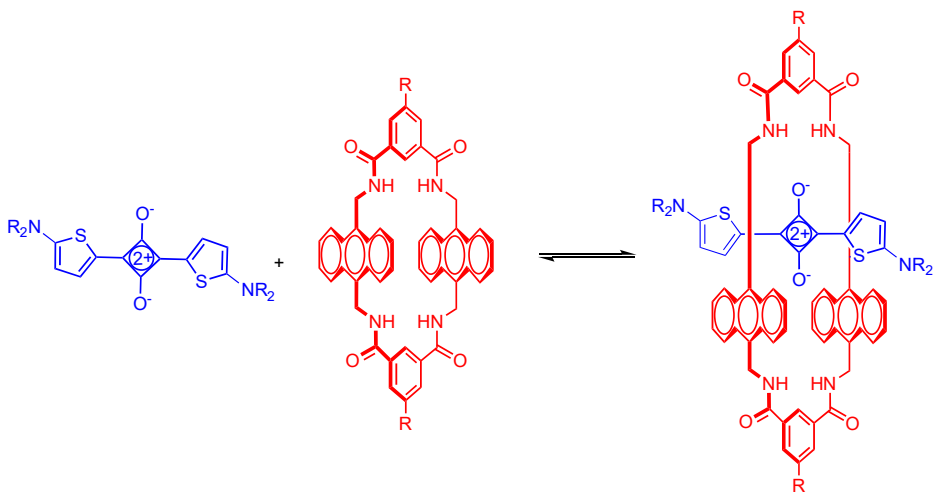

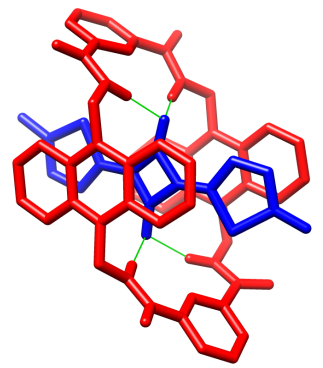

Threaded complex stabilized by fou hydrogen bonds and aromatic stacking

Scheme 1. Encapsulation of a bis(aminothiophene)squaraine dye by a tetralactam macrocycle that has two anthracene sidewalls.

We decided to develop a new set of squaraine chromophores with incrementally extended absorption/emission wavelengths. We knew that squaraine structures containing aminophenyl or aminothiophene units would be useful for operation in the region of 600-700 nm [27]. The real challenge was to develop a stable squaraine chromophore with the extended $\pi$-conjugation needed to reach $800 \mathrm{~nm}$ and also allow macrocycle threading. After some preliminary experimentation, we discovered that squaraine dyes could be prepared with attached aminothienothiophene units, and that these dyes exhibited the desired optical and supramolecular properties. Herein, in Scheme 2 we showcase this discovery by describing three organic-soluble dyes (S1-S3) that were easily prepared from commercially available materials in a few steps, and water-soluble analogues (S1PEG-S3PEG) that were obtained by appending long polyethylene glycol (PEG) chains. We find that the dyes form supramolecular complexes with the tetralactam macrocycles M1 or M2 to produce a suite of 12 fluorescent compounds that span the absorption window of 600-800 nm, making them a very attractive set of dyes for a wide range of future biological imaging applications. 


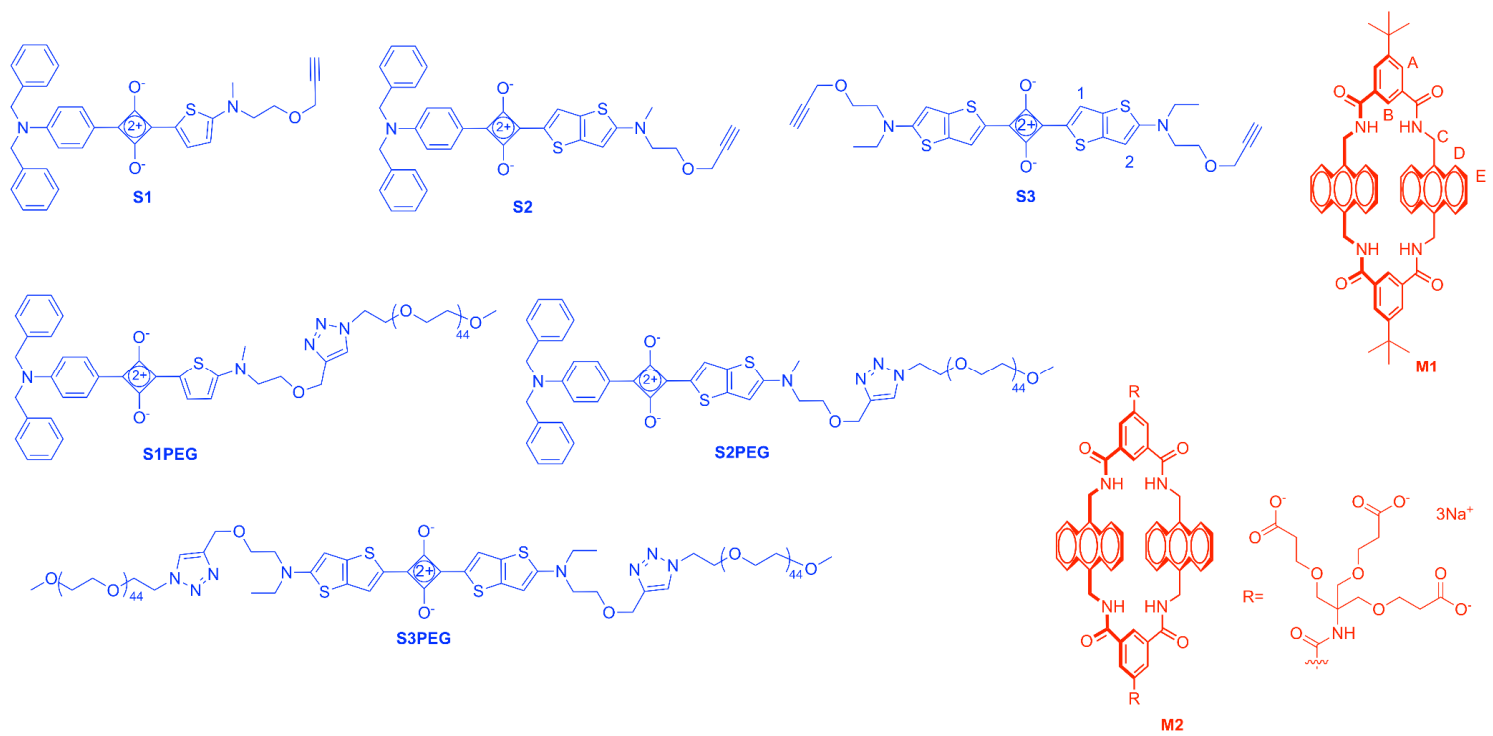

Scheme 2. Structures of squaraine dyes and macrocycles used in this study with relevant atom labels.

\section{Results and Discussion}

\subsection{Synthesis}

The unsymmetrical squaraines, S1 and S2, were synthesized by similar procedures using $N, N$-dibenzylaminophenyl semisquaraine 2 as a common building block (Schemes 3 and 4 ). In the first case, condensation of $\mathbf{2}$ with 2-aminothiophene derivative $\mathbf{1}$ furnished organic-soluble squaraine $\mathbf{S 1}$ in 77\% yield, which was subsequently converted into water-soluble squaraine S1PEG by conducting a copper-catalyzed alkyne-azide cycloaddition reaction with 3 . In the second case, the appropriate 2-aminothienothiophene 6 was produced in three steps [28] and then condensed with 2 to give organic-soluble squaraine $\mathbf{S} 2$ in $58 \%$ yield. A subsequent cycloaddition reaction with 3 provided the water-soluble squaraine S2PEG.

The symmetrical squaraine S3 was prepared (Scheme 5) in 92\% yield by condensing squaric acid with two molar equivalents of 2-aminothienothiophene 8 . The reaction was complete after 2 hours and the air-stable product appeared as a golden brown precipitate that could be isolated by simple filtration. A subsequent cycloaddition reaction with two molar equivalents of 3 provided the water-soluble squaraine S3PEG.

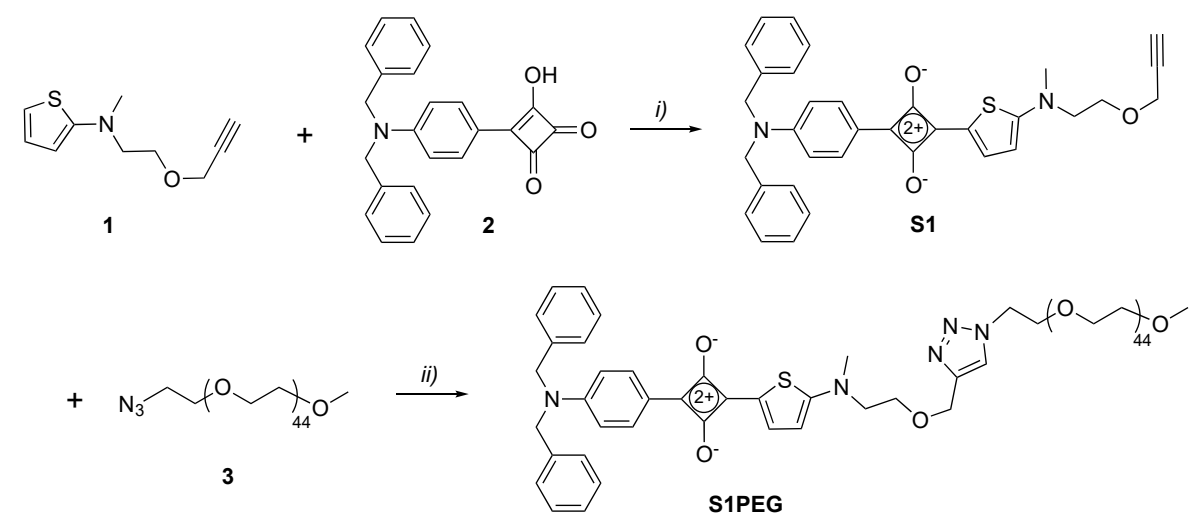

Scheme 3. Reagents and conditions: (i) Benzene, 1-butanol, $100{ }^{\circ} \mathrm{C}, 2 \mathrm{~h}, 77 \%$; (ii) Tris[(1-benzyl- $1 H$ 1,2,3-triazol-4-yl)methyl]amine (TBTA) $\mathrm{Cu}(\mathrm{I}) \mathrm{Br}$, triethylamine, $\mathrm{CHCl}_{3}, \mathrm{rt}, 12 \mathrm{~h}, 92 \%$. 


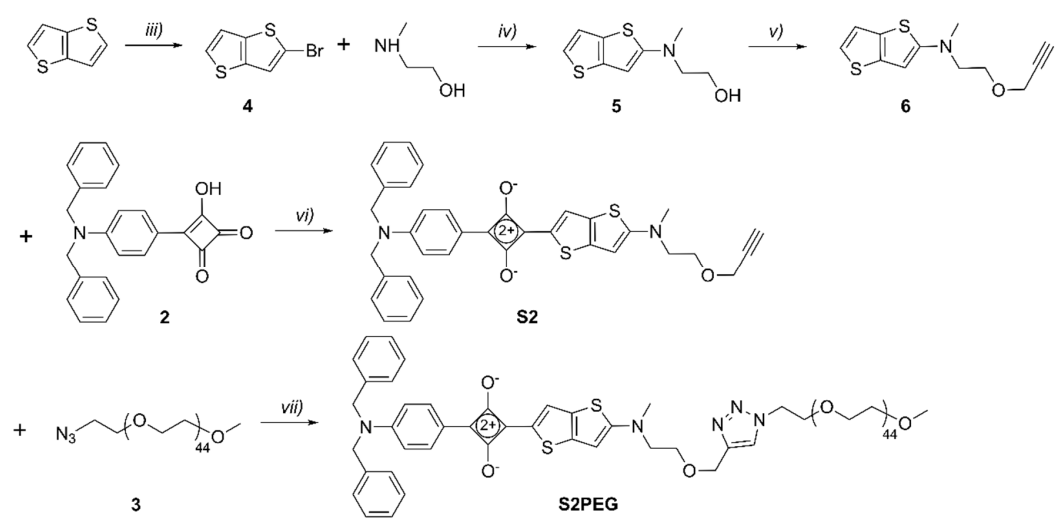

Scheme 4. Reagents and conditions: (iii) $\mathrm{N}$-bromosuccinimide, $\mathrm{AcOH}, 2 \mathrm{~h}, \mathrm{rt}, 81 \%$; (iv) $\mathrm{K}_{3} \mathrm{PO}_{4} \cdot \mathrm{H}_{2} \mathrm{O}$, $\mathrm{Cu}^{0}$, CuI, $90{ }^{\circ} \mathrm{C}, 5 \mathrm{~h}, 46 \%$; (v) Propargyl bromide, $\mathrm{NaOH}$, toluene, tetrabutylammonium (TBA) $\mathrm{HSO}_{4}$, rt, 5 h, 97\%; (vi) Benzene, 1-butanol, $100{ }^{\circ} \mathrm{C}, 2$ h, 58\%; (vii) TBTACu(I)Br, N,N-Diisopropylethylamine (DIPEA), $\mathrm{CHCl}_{3}, \mathrm{rt}, 12 \mathrm{~h}, 55 \%$.

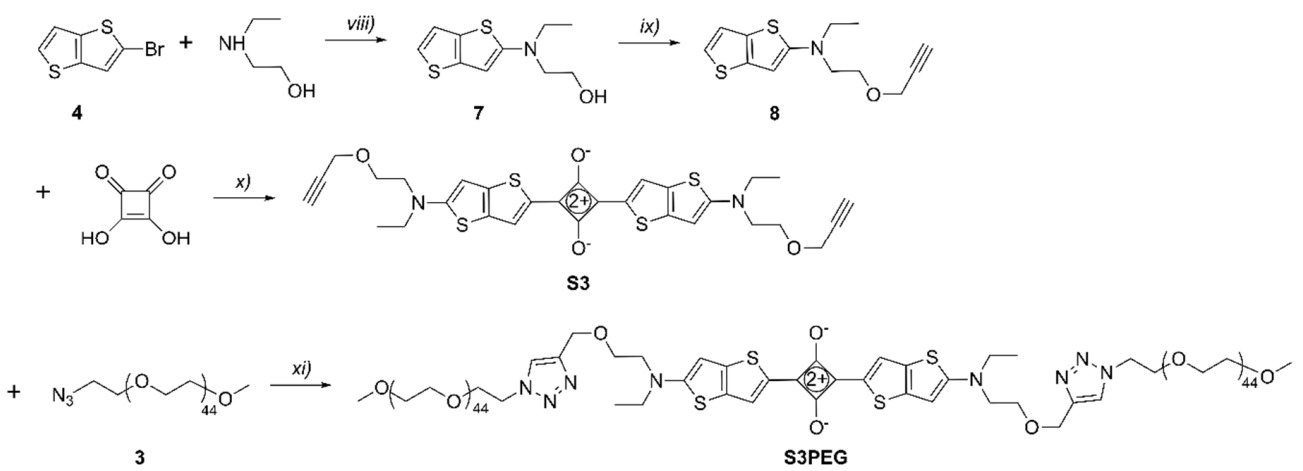

Scheme 5. Reagents and conditions: (viii) $\mathrm{K}_{3} \mathrm{PO}_{4} \cdot \mathrm{H}_{2} \mathrm{O}, \mathrm{Cu}^{0}$, CuI, $90{ }^{\circ} \mathrm{C}, 5 \mathrm{~h}, 51 \%$; (ix) Propargyl bromide, $\mathrm{NaOH}$, toluene, $\mathrm{TBA} \mathrm{HSO}_{4}, \mathrm{rt}, 5$ h, 84\%; (x) Benzene, 1-butanol, $100{ }^{\circ} \mathrm{C}, 2$ h, 92\%; (xi) TBTACu(I)Br, DIPEA, $\mathrm{CHCl}_{3}$, rt, sonication, $4 \mathrm{~h}, 42 \%$.

\subsection{Macrocycle Threading in Chloroform}

As a series, squaraines S1, S2 and S3 have increasing $\pi$-conjugation, and they are soluble in organic solvents such as $\mathrm{CHCl}_{3}$. A key molecular design feature is the small $\mathrm{N}$-alkyl group (either $\mathrm{N}$-methyl or $\mathrm{N}$-ethyl) at one or both ends of the central chromophore, which ensures that macrocycle threading is facile [17]. Threading studies in $\mathrm{CHCl}_{3}$ were performed by mixing separate samples of S1, S2 and S3 with one molar equivalent of organic-soluble macrocycle M1. In each case there was an immediate 20-35 nm red-shift in the squaraine absorption and emission maxima wavelength (Figure 1) which is diagnostic of squaraine encapsulation by M1.
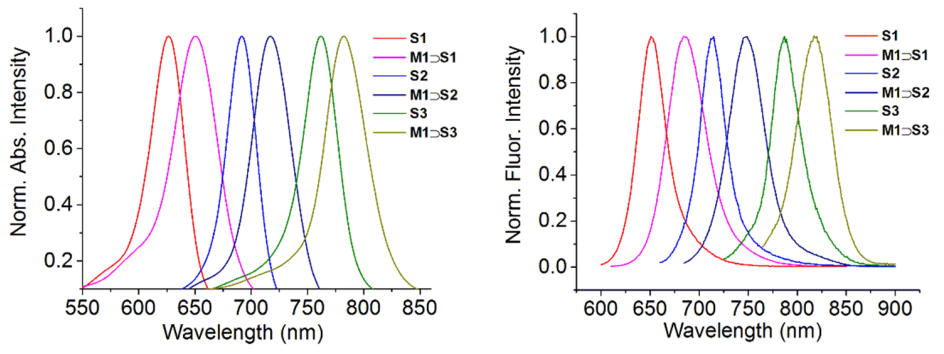

Figure 1. Absorption (left) and emission (right) maxima for separate solutions of S1, S2 and S3 and their threaded complexes with $\mathbf{M 1}$ in $\mathrm{CHCl}_{3}$. 
In the case of S3, the macrocycle threading process was characterized using ${ }^{1} \mathrm{H}-\mathrm{NMR}$. In Figure 2 is a comparison of partial ${ }^{1} \mathrm{H}-\mathrm{NMR}$ spectra for separate solutions of $\mathbf{S} 3, \mathbf{M} 1$ and $\mathbf{M} 1 \supset \cap \mathbf{S} 3 \mathrm{in} \mathrm{CDCl}_{3}$. Squaraine S3 can adopt two low-energy conformations that differ in the relative orientation of the thienothiophene units, which can have a cis or a trans relationship. The ${ }^{1} \mathrm{H}-\mathrm{NMR}$ spectrum for free S3 shows single peaks for protons 1 and 2 suggesting fast exchange between cis and trans conformations. A sample containing a 1:1 mixture of S3 and M1 instantly formed M1 $\supset$ S3 in a quantitative yield. The chemical shifts for M1 $\supset \bigcap$ S3 indicated encapsulation of the squaraine inside the macrocycle as illustrated by the molecular model in Figure 3. Notably, there are large downfield changes in chemical shift for the macrocycle NH residues and protons B, and large upfield changes in the chemical shift for macrocycle protons D and E. Moreover, the spectral patterns for the macrocycle unambiguously indicate that the encapsulated squaraine predominantly adopts a $\mathrm{C}_{2}$-symmetric trans conformation, with a small fraction of the encapsulated squaraine $(<10 \%)$ in a cis conformation. For example, the major signal for the macrocycle B protons is a singlet at $9.33 \mathrm{ppm}$, which can only arise if the encapsulated squaraine is trans. In contrast, the minor signal for the macrocycle B protons is split into two singlets around $9.22 \mathrm{ppm}$, which implies that the encapsulated squaraine is cis. The peaks for squaraine protons 1 and 2 in encapsulated S3 are sharp due to hindered rotation of the squaraine single bonds when S3 is inside the macrocycle. Moreover, the large upfield change in chemical shift for squaraine proton 1 and the relatively negligible change in chemical shift for proton 2 are both consistent with the anisotropic NMR shielding zones predicted by the molecular model in Figure 3.

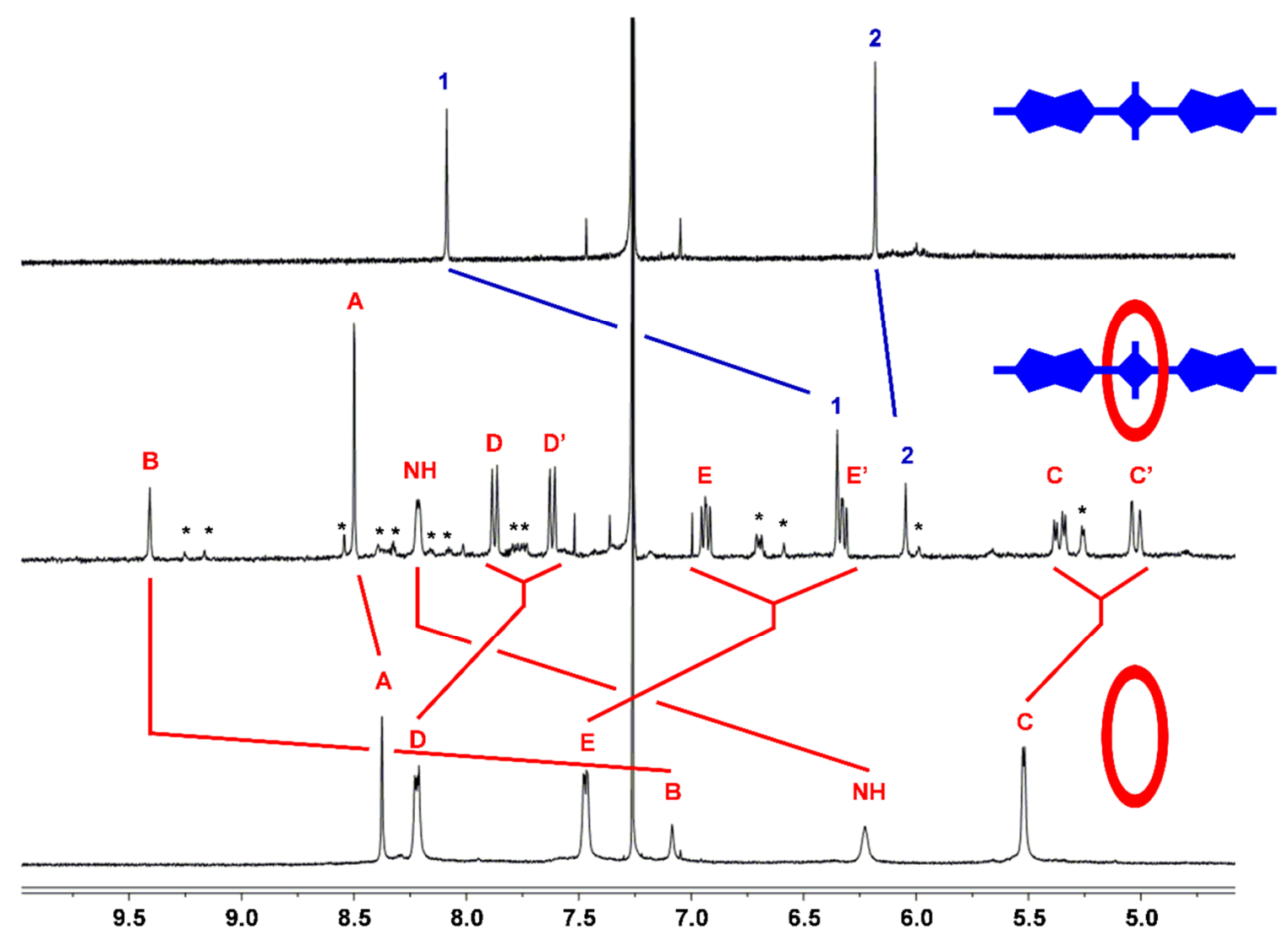

Figure 2. Comparison of partial ${ }^{1} \mathrm{H}-\mathrm{NMR}$ spectra for separate samples of free S3, M1 $\supset \cap \mathbf{S} 3$, and free $\mathrm{M1}$ in $\mathrm{CDCl}_{3}$. Atom labels are provided in Scheme 2. Red and blue lines indicate major changes in chemical shifts upon complexation. * designates NMR signals for the minor M1 $\supset \cap$ S3 complex with encapsulated S3 in a cis conformation (trans/cis ratio for encapsulated S3 is $>10: 1$ ). See Scheme 2 for atom labels which are numbers (for S3) and letters (for M1). 

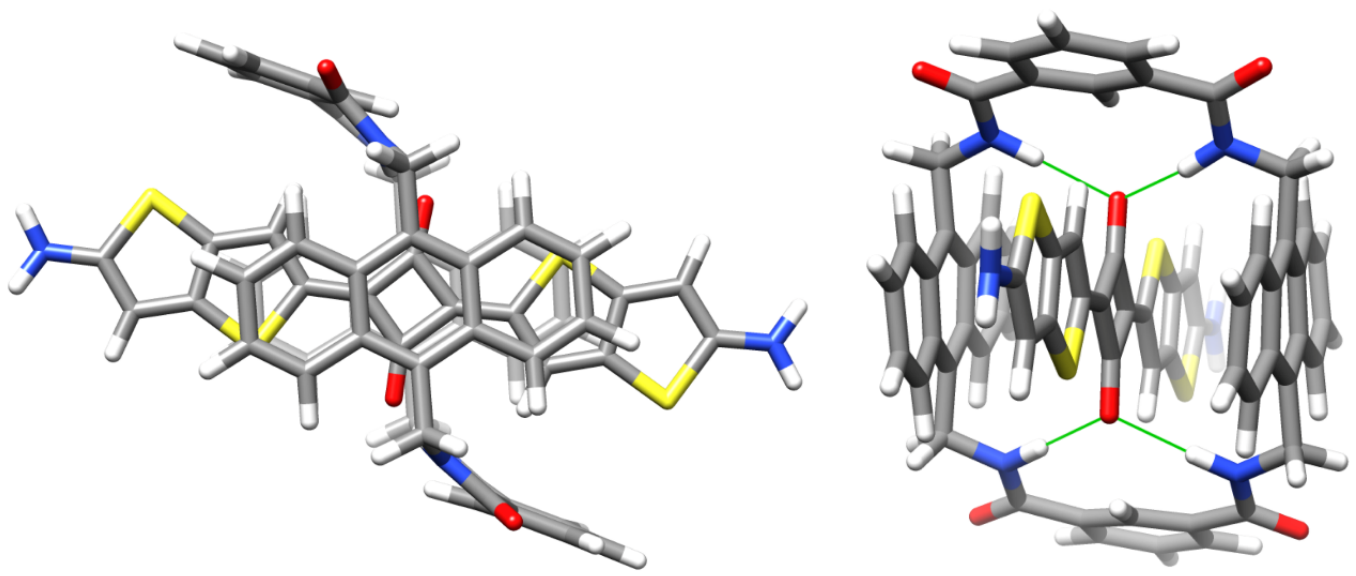

Figure 3. Molecular model of M1 $\supset \cap \mathbf{S} 3$ (squaraine and macrocycle alkyl groups removed for clarity), calculated by the semiempirical method at PM7 level, showing the encapsulated squaraine in a trans conformation and ends of the squaraine's thienothiophene units outside the shielding zone of M1. (left) front view, (right) side view. Hydrogen bonds between macrocycle NH residues and squaraine oxygen atoms are indicated by green lines. Color code for atoms: grey = carbon, blue = hydrogen, blue $=$ nitrogen, red $=$ oxygen, yellow $=$ sulfur.

\subsection{Macrocycle Threading in Water}

Preliminary threading studies in water were performed by mixing separate solutions of water-soluble squaraines S1PEG, S2PEG and S3PEG with one molar equivalent of water-soluble macrocycle M2. Shown in Figure 4 is a photograph of the different samples and also the absorption and emission maxima. The absorption spectra for free S1PEG, and especially S2PEG and S3PEG, exhibit band broadening due to self-aggregation of the dyes. But as hoped, macrocycle threading produced three changes in spectral properties: (a) A significant sharpening of the squaraine absorption bands, (b) a 20-35 nm red-shift in the squaraine absorption and emission maxima wavelength, and (c) a significant increase in fluorescence quantum yield.
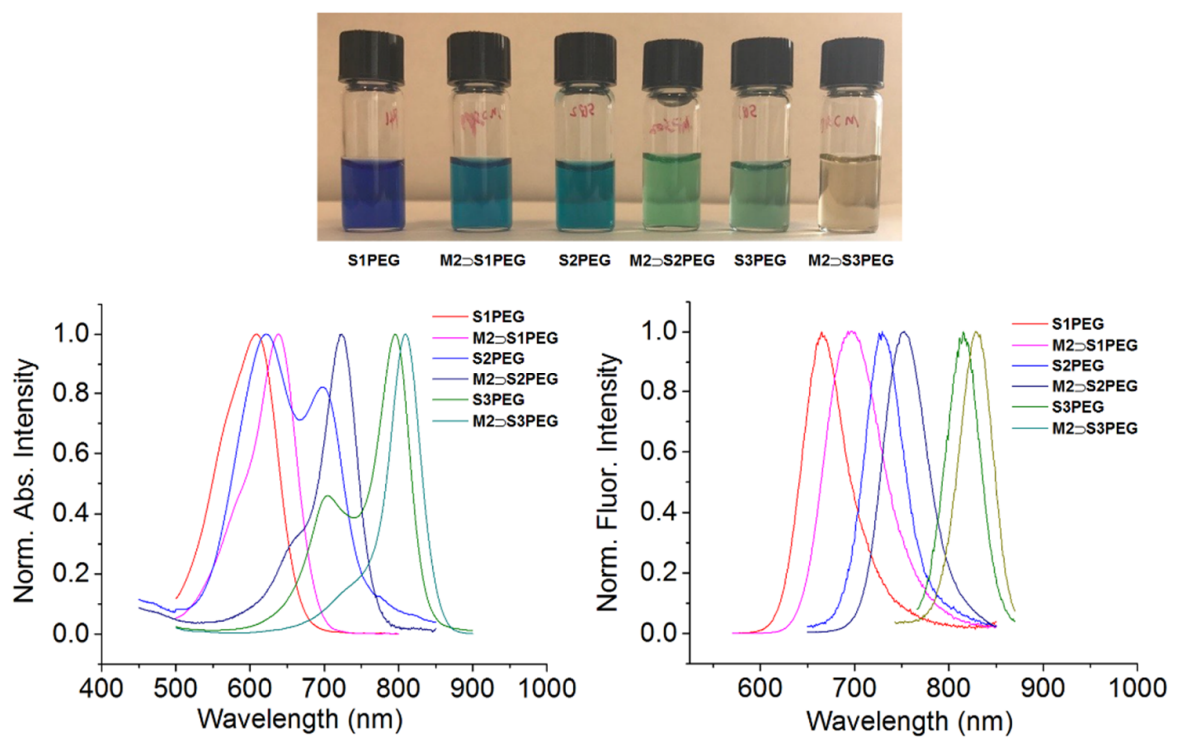

Figure 4. (top) Photograph of separate solutions containing free squaraine or macrocycle complex in $\mathrm{H}_{2} \mathrm{O}$. Absorption (bottom left) and emission (bottom right) maxima for separate solutions containing squaraine or macrocycle complex in water. 
The association constants for threading of M2 by S1PEG, S2PEG or S3PEG in water were measured by fluorescence titration (Figure 5, Figures S1 and S2) and the values of $K_{a}$ are listed in Table 1. The symmetrical thienothiophene-based squaraine S3PEG has essentially the same nanomolar affinity for $\mathbf{M} 2$ as analogous but shorter symmetrical thiophene-based squaraines [14]. Although the extended chromophore in S3PEG has a larger hydrophobic surface area, it does not translate into higher affinity for M2, presumably because there is no increase in the amount of hydrophobic surface area that is buried by complexation (see the molecular model in Figure 3). The $\mathrm{K}_{\mathrm{a}}$ values for unsymmetrical S1PEG and S2PEG are 7.8 and 5.3 times higher than S3PEG because these dyes have terminal $\mathrm{N}, \mathrm{N}$-dibenzyl groups which are known to stabilize the threaded complexes by stacking with peripheral surfaces of the surrounding macrocycle [29]. For each water-soluble squaraine, the second order rate constant for macrocycle threading, $\mathrm{k}_{\mathrm{on}}$, was measured using a stopped flow device that monitored the increase in fluorescence after mixing the squaraine and macrocycle. As shown in Figure 5, threading of M2 by S3PEG was complete in less than a minute when the concentration of each binding partner was $250 \mathrm{nM}$. Compared to S3PEG, the threading of M2 by S1PEG and S2PEG (Figures S1 and S2) was 25 and 100 times faster, respectively, which was expected based on the known dependence of $k_{\text {on }}$ on the steric size of $N$-alkyl groups at the end of the squaraine chromophore [17]. Squaraines S1PEG and S2PEG have $N$-methyl groups whereas squaraine S3PEG has larger $N$-ethyl groups which were needed to increase the dye solubility.
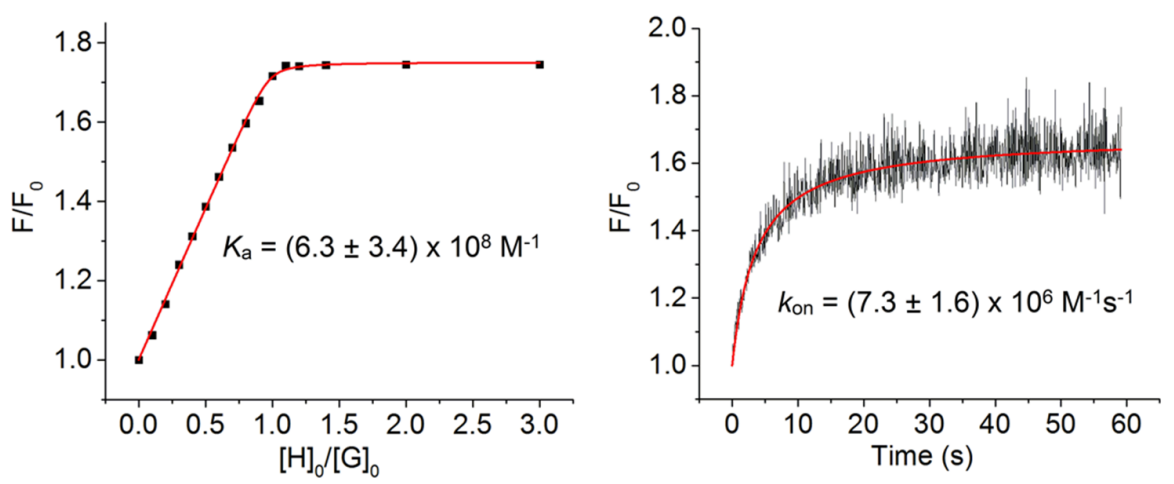

Figure 5. (left) Fluorescence (ex: $809 \mathrm{~nm}$, em: $829 \mathrm{~nm}$, slit $5 \mathrm{~nm}$ ) titration isotherm for incremental addition of M2 to a solution of S3PEG (250 nM) in $\mathrm{H}_{2} \mathrm{O}$ at $25^{\circ} \mathrm{C}$. (right) Threading kinetic profile generated by mixing equal molar concentration ( $50 \mathrm{nM}$ each) of S3PEG and M2 in a stopped flow device (ex: $809 \mathrm{~nm}$, em: $829 \mathrm{~nm}$, slit $5 \mathrm{~nm}$ ). The red lines are computer fits of experimental data to 1:1 binding model or second order kinetic model, respectively.

Table 1. Association constant $\left(K_{\mathrm{a}}\right)$ and rate constant $\left(k_{\mathrm{on}}\right)$ for squaraine threading of $\mathbf{M} 2$ in $\mathrm{H}_{2} \mathrm{O}$ at $25^{\circ} \mathrm{C}$.

\begin{tabular}{ccc}
\hline & $\boldsymbol{K}_{\mathrm{a}}\left(\mathbf{M}^{\mathbf{- 1}}\right)$ & $\boldsymbol{k}_{\text {on }}\left(\mathbf{M}^{-\mathbf{1}} \mathbf{s}^{-\mathbf{1}} \mathbf{)}\right.$ \\
\hline S1PEG & $(4.9 \pm 2.0) \times 10^{9}$ & $(1.9 \pm 0.2) \times 10^{8}$ \\
S2PEG & $(3.4 \pm 1.5) \times 10^{9}$ & $(7.0 \pm 1.0) \times 10^{8}$ \\
S3PEG & $(6.3 \pm 3.4) \times 10^{8}$ & $(7.3 \pm 1.6) \times 10^{6}$ \\
\hline
\end{tabular}

\subsection{Photophysical Properties}

In Table 2 is a summary of the photophysical properties of the six different dye systems in water. The photostability of each squaraine and its macrocycle complex in water was monitored by continuous NIR light excitation over $15 \mathrm{~h}$ and in each case there was no or little loss in sample fluorescence intensity (Figures S3-S5). The chemical stabilities of the dyes and their macrocycle complexes were tested by monitoring the fluorescence intensity over time in the presence of strongly nucleophilic $\mathrm{Na}_{2} \mathrm{~S}$ in water (Figures $\mathrm{S} 6-\mathrm{S} 8$ ). All three dyes were quickly bleached by the $\mathrm{Na}_{2} \mathrm{~S}$, whereas 
the corresponding macrocycle complexes were quite stable, which is compelling evidence that the encapsulated squaraines were inside the protective macrocycle M2. This combination of high resistance to chemical and photobleaching exhibited by the complexes is quite notable for such highly $\pi$-extended chromophores [3].

Table 2. Photophysical properties of squaraines and their complexes with $\mathbf{M} 2$ in $\mathrm{H}_{2} \mathrm{O}$.

\begin{tabular}{ccccccc}
\hline & S1PEG & M2 $\supset \cap$ S1PEG & S2PEG & M2 $\supset \cap$ S2PEG & S3PEG & M2 $\supset \cap$ S3PEG \\
\hline Abs $(\mathrm{nm})$ & 608 & 638 & 695 & 722 & 795 & 809 \\
Em $(\mathrm{nm})$ & 665 & 697 & 731 & 753 & 815 & 829 \\
$\Phi_{f}^{a}$ & $6 \%$ & $25 \%$ & $3 \%$ & $19 \%$ & $7 \%$ & $11 \%$ \\
\hline
\end{tabular}

Quantum yields of S1PEG and M2 $\supset \cap$ S1PEG were measured relative to bis $(N, N$-dimethylaminophenyl)squaraine, quantum yields of S2PEG and M2 $\supset \cap$ S2PEG were measured relative to cryptocyanine, and quantum yields of S3PEG and M2 $\supset \cap$ S3PEG were measured relative to ICG [30].

Presently, the only NIR dye that is approved for use in humans is indocyanine green (ICG). Although ICG is employed extensively, it is also known to have nonoptimal performance properties and there is an active community effort to find replacement dyes with very similar absorption/emission wavelengths. Shown in Figure 6 is a comparison of the absorption and emission maxima for ICG, S3PEG and M2 $\supset \cap$ S3PEG in water. The absorption spectra for ICG and S3PEG both exhibited blue-shifted aggregation bands whereas the maxima band for M2 $\supset \cap$ S3PEG was relatively sharp and narrow (Figure 6). To compare the fluorescence quantum yields, the concentrations of each sample were adjusted to produce the same absorbance value (0.08) at $750 \mathrm{~nm}$, and the fluorescent emission spectrum was collected with excitation at $750 \mathrm{~nm}$. Integration of the emission bands in Figure 6 indicated that the fluorescence quantum yields for S3PEG and M2 $\supset$ S3PEG were 1.3 and 2 times higher than ICG (Table S1).
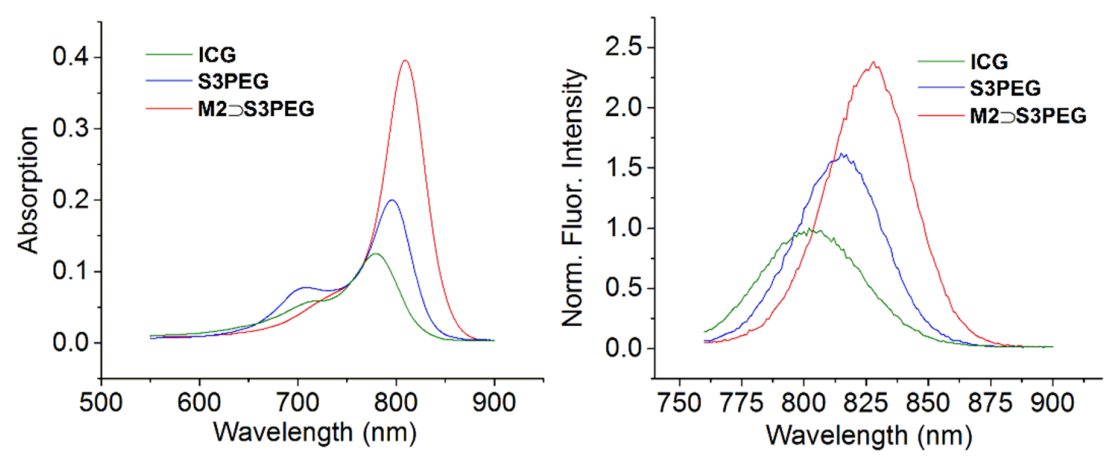

Figure 6. (left) Absorbance and (right) emission spectra (ex: $750 \mathrm{~nm}$ ) of ICG, S3PEG, M2 $\supset \cap$ S3PEG with concentration adjusted to give identical absorbance values (0.08) at $750 \mathrm{~nm}$ in $\mathrm{H}_{2} \mathrm{O}$.

A unique photophysical feature of these threaded squaraine macrocycle complexes is the option of squaraine excitation by internal energy transfer [14]. That is, $375 \mathrm{~nm}$ excitation of the anthracene sidewalls of the surrounding macrocycle (M2) is followed by efficient internal energy transfer within the complex and excitation of the encapsulated squaraine. This capability raises the possibility of multiplex excitation of multiple dyes in the same sample. Shown in Figure 7 is the two-color emission spectrum that was observed when 1:1 mixture of M2 $\supset \cap$ S1PEG and M2 $\supset \cap$ S3PEG in water was excited at $375 \mathrm{~nm}$. The two emission bands nicely match the popular Cy5 and Cy7 emission channels that are commonly used for biological imaging. Single wavelength excitation and multiplex detection is a valuable tool in orthogonal fluorescence imaging, and is likely to be very helpful in technologies such as fluorescence-guided surgery and cancer tissue histology, where there is a desire to simultaneously identify the location of different molecular probes that label distinct biological targets [31,32]. 


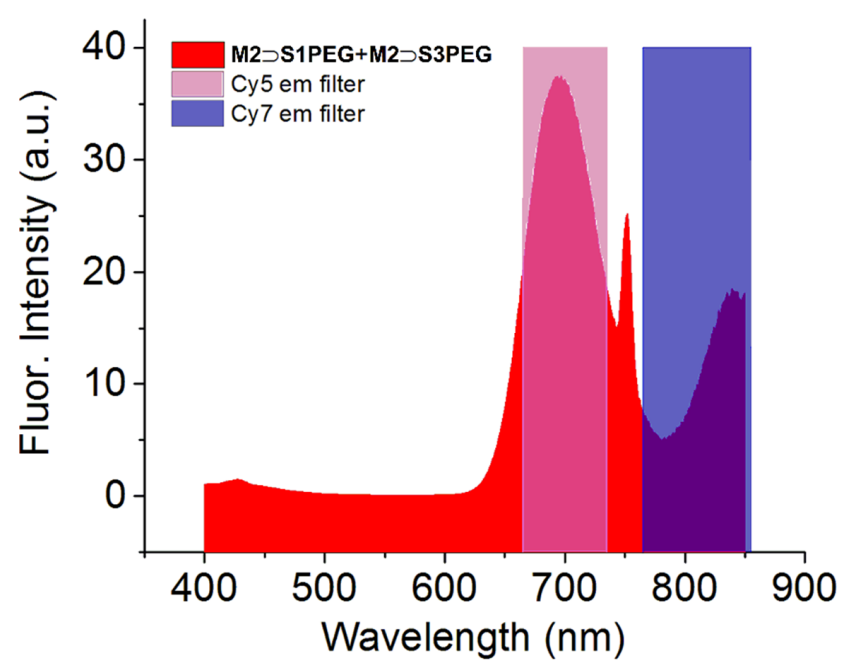

Figure 7. Two color emission by single excitation $(375 \mathrm{~nm})$ of a 1:1 mixture containing M2 $\supset \cap$ S1PEG and M2 $\supset$ S3PEG in $\mathrm{H}_{2} \mathrm{O}$. The peak at $750 \mathrm{~nm}$ is an artifact caused by the excitation at $375 \mathrm{~nm}$.

\section{Materials and Methods}

\subsection{General}

${ }^{1} \mathrm{H}$ and ${ }^{13} \mathrm{C}-\mathrm{NMR}$ spectra were recorded on Bruker AVANCE III HD 400 (Billerica, MA, USA) and $500 \mathrm{MHz}$ spectrometer (Billerica, MA, USA) Chemical shift was presented in ppm and referenced by residual solvent peak. Mass spectrometry (MS) was either performed using a Bruker microTOF II spectrometer (Billerica, MA, USA) with electron spray ionization (ESI) or Bruker Autoflex III (Billerica, MA, USA) with matrix-assisted laser desorption/ionization (MALDI). Commercially available solvents and chemicals were used without further purification unless otherwise stated. Water was de-ionized and micro filtered. Flash column chromatography was performed using Biotage flash column chromatography purification system with SNAP Ultra cartridges (Charlotte, NC, USA). All cartridges used silica gel as stationary phase unless otherwise stated.

\subsection{Synthesis}

Compound $\mathbf{1}$ [17], 2 [33] and 3 [34] were prepared using previously reported literature methods.

S1: Compound 1 (80 mg, $0.410 \mathrm{mmol})$ and compound $2(150 \mathrm{mg}, 0.406 \mathrm{mmol})$ were dissolved in a mixture of 1-butanol $(15 \mathrm{~mL})$ and benzene $(45 \mathrm{~mL})$ and the reaction mixture was heated to reflux for $2 \mathrm{~h}$ with Dean-Stark distillation. The solvent was removed and the residue was purified by column chromatography using $0-10 \% \mathrm{MeOH} / \mathrm{CHCl}_{3}$ to produce pure $\mathbf{S} 1$ as a blue solid (172 $\mathrm{mg}, 77 \%$ yield). ${ }^{1} \mathrm{H}-\mathrm{NMR}\left(500 \mathrm{MHz}, \mathrm{CDCl}_{3}\right) \delta 8.15-8.12(\mathrm{~m}, 2 \mathrm{H}), 8.11(\mathrm{~s}, 1 \mathrm{H}), 7.32(\mathrm{dd}, J=8.1,6.6 \mathrm{~Hz}, 4 \mathrm{H}), 7.29-7.24(\mathrm{~m}$, 2H), 7.23-7.17 (m, $4 \mathrm{H}), 6.79(\mathrm{~d}, J=9.1 \mathrm{~Hz}, 2 \mathrm{H}), 6.47(\mathrm{~d}, J=5.1 \mathrm{~Hz}, 1 \mathrm{H}), 4.73(\mathrm{~s}, 4 \mathrm{H}), 4.11(\mathrm{~d}, J=2.4 \mathrm{~Hz}$, 2H), $3.77(\mathrm{~s}, 2 \mathrm{H}), 3.70(\mathrm{t}, J=4.9 \mathrm{~Hz}, 2 \mathrm{H}), 3.26(\mathrm{~s}, 3 \mathrm{H}), 2.41(\mathrm{t}, J=2.4 \mathrm{~Hz}, 1 \mathrm{H}) .{ }^{13} \mathrm{C}-\mathrm{NMR}(126 \mathrm{MHz}$, $\left.\mathrm{CDCl}_{3}\right) \delta 181.00,180.74,179.96,176.30,173.77,152.09,142.94,137.23,130.80,129.10,128.89,127.60$, $126.72,121.30,115.67,113.55,112.79,79.08,75.59,66.79,58.79,56.34,54.25,43.10$. HRMS-ESI $\mathrm{m} / \mathrm{z}$ $547.2026\left([\mathrm{M}+\mathrm{H}]^{+}, \mathrm{C}_{34} \mathrm{H}_{31} \mathrm{~N}_{2} \mathrm{O}_{3} \mathrm{~S}^{+}\right.$, calc. 547.2050).

S1PEG: Compound S1 (12 mg, $0.021 \mathrm{mmol})$, azido-mPEG 45 (40 mg, $0.020 \mathrm{mmol})$, triethylamine (2 drops) and TBTACu(I)Br $(2 \mathrm{mg})$ were dissolved in $\mathrm{CHCl}_{3}(5 \mathrm{~mL})$ and the reaction mixture was stirred at room temperature for $12 \mathrm{~h}$. After removing the solvent, the residue was purified by column chromatography using $0-10 \% \mathrm{MeOH} / \mathrm{CHCl}_{3}$ (containing $0.2 \% \mathrm{NH}_{4} \mathrm{OH}$ ) to obtain pure S1PEG as a blue solid (48 mg, 92\% yield). ${ }^{1} \mathrm{H}-\mathrm{NMR}\left(500 \mathrm{MHz}, \mathrm{CDCl}_{3}\right) \delta 8.18(\mathrm{~d}, J=5.0 \mathrm{~Hz}, 1 \mathrm{H}), 8.15(\mathrm{~d}, J=9.2 \mathrm{~Hz}$, 2H), $7.70(\mathrm{~s}, 1 \mathrm{H}), 7.37-7.31(\mathrm{~m}, 4 \mathrm{H}), 7.30-7.27(\mathrm{~m}, 2 \mathrm{H}), 7.23-7.18(\mathrm{~m}, 4 \mathrm{H}), 6.81(\mathrm{~d}, J=9.2 \mathrm{~Hz}, 2 \mathrm{H}), 6.50$ $(\mathrm{d}, J=5.0 \mathrm{~Hz}, 1 \mathrm{H}), 4.73(\mathrm{~s}, 4 \mathrm{H}), 4.62(\mathrm{~s}, 2 \mathrm{H}), 4.52(\mathrm{dd}, J=5.5,4.6 \mathrm{~Hz}, 2 \mathrm{H}), 3.87-3.81(\mathrm{~m}, 4 \mathrm{H}), 3.79-3.72$ 
$(\mathrm{m}, 2 \mathrm{H}), 3.68-3.46(\mathrm{~m}, 203 \mathrm{H}), 3.37(\mathrm{~s}, 3 \mathrm{H}), 3.30(\mathrm{~s}, 3 \mathrm{H})$. MS-MALDI (DHBA as matrix) showed a set of peaks around 2363 which reflected the polydispersity of the $\mathrm{PEG}_{45}$ chains.

2-Bromothieno[3,2-b]thiophene (4): Thieno[3,2-b]thiophene $(1.0 \mathrm{~g}, 7.13 \mathrm{mmol})$ was dissolved in acetic acid $(10 \mathrm{~mL}) . \mathrm{N}$-bromosuccinimide $(1.27 \mathrm{~g}, 7.13 \mathrm{mmol})$ was added and the reaction mixture was stirred at room temperature for $2 \mathrm{~h}$. Solvent was removed and the residue was dissolved in diethyl ether $(80 \mathrm{~mL})$ and washed with $\mathrm{NaOH}(1 \mathrm{M}, 100 \mathrm{~mL} \times 3), \mathrm{H}_{2} \mathrm{O}(100 \mathrm{~mL} \times 3)$ and brine $(100 \mathrm{~mL})$. The resulting solution was dried over $\mathrm{Na}_{2} \mathrm{SO}_{4}$, and the solvent was removed by rotary evaporation to obtain pure 4 as a light yellow liquid (1.3 g, 81\% yield). ${ }^{1} \mathrm{H}-\mathrm{NMR}\left(500 \mathrm{MHz}, \mathrm{CDCl}_{3}\right) \delta 7.40(\mathrm{ddd}, J=5.7,3.0,1.5 \mathrm{~Hz}$, $1 \mathrm{H}), 7.28(\mathrm{~d}, J=4.1 \mathrm{~Hz}, 1 \mathrm{H}), 7.20-7.14(\mathrm{~m}, 1 \mathrm{H}) .{ }^{13} \mathrm{C}-\mathrm{NMR}\left(126 \mathrm{MHz}, \mathrm{CDCl}_{3}\right) \delta 127.57,126.78,122.32$, $121.98,119.60,119.24$. HRMS-ESI $m / z$ 217.8837 ([M] ${ }^{+}, \mathrm{C}_{6} \mathrm{H}_{3} \mathrm{BrS}_{2}{ }^{+}$, calc. 217.8860).

2-(methyl(thieno[3,2-b]thiophen-2-yl)amino)ethan-1-ol (5): Compound 4 (1.3 g, $5.8 \mathrm{mmol}), \mathrm{Cu}^{0}(70 \mathrm{mg}$, $1.2 \mathrm{mmol}), \mathrm{CuI}(220 \mathrm{mg}, 1.2 \mathrm{mmol})$ and $\mathrm{K}_{3} \mathrm{PO}_{4} \cdot \mathrm{H}_{2} \mathrm{O}(2.7 \mathrm{~g}, 11.6 \mathrm{mmol})$ were suspended in 2-(methylamino)ethanol $\left(15 \mathrm{~mL}\right.$ ). The reaction mixture was stirred at $90^{\circ} \mathrm{C}$ over $5 \mathrm{~h}$. After cooling to room temperature, $\mathrm{H}_{2} \mathrm{O}(80 \mathrm{~mL})$ was added, and the reaction mixture was extracted with diethyl ether $(100 \mathrm{~mL} \times 3)$. The organic phase was combined and dried over $\mathrm{Na}_{2} \mathrm{SO}_{4}$, the solvent was removed and the residue was purified by column chromatography (neutral $\mathrm{Al}_{2} \mathrm{O}_{3}$ as stationary phase) using $10-40 \%$ EtOAc/hexane to obtain pure 5 as a light yellow solid ( $570 \mathrm{mg}, 46 \%$ yield). ${ }^{1} \mathrm{H}-\mathrm{NMR}(500 \mathrm{MHz}$, Acetone- $\left.d_{6}\right) \delta 7.10(\mathrm{dd}, J=5.2,0.6 \mathrm{~Hz}, 1 \mathrm{H}), 7.07(\mathrm{~d}, J=5.2 \mathrm{~Hz}, 1 \mathrm{H}), 6.12(\mathrm{~d}, J=0.7 \mathrm{~Hz}, 1 \mathrm{H}), 3.99(\mathrm{t}$, $J=5.5 \mathrm{~Hz}, 1 \mathrm{H}), 3.80(\mathrm{q}, J=5.7 \mathrm{~Hz}, 2 \mathrm{H}), 3.40(\mathrm{t}, J=5.9 \mathrm{~Hz}, 2 \mathrm{H}), 3.00(\mathrm{~s}, 3 \mathrm{H}) .{ }^{13} \mathrm{C}-\mathrm{NMR}(126 \mathrm{MHz}$, Acetone- $\left.d_{6}\right) \delta 206.11,160.53,139.67,120.16,119.69,93.96,59.29,57.85,40.43,29.67,29.51,29.36,29.21$, 29.05. HRMS-ESI $m / z 214.0379\left([\mathrm{M}+\mathrm{H}]^{+}, \mathrm{C}_{9} \mathrm{H}_{12} \mathrm{NOS}_{2}{ }^{+}\right.$, calc. 214.0355).

$N$-methyl-N-(2-(prop-2-yn-1-yloxy)ethyl)thieno[3,2-b]thiophen-2-amine (6): Propargyl bromide (900 $\mu \mathrm{L}$, $8.0 \mathrm{mmol}$ ) was added to a mixture of compound $5(570 \mathrm{mg}, 2.7 \mathrm{mmol})$, aqueous $\mathrm{NaOH}(15 \mathrm{~mL}, 50 \%$ $\mathrm{w} \%$ ) and toluene $(15 \mathrm{~mL})$. TBA $\mathrm{HSO}_{4}(200 \mathrm{mg})$ was added to the mixture as a phase transfer reagent and the resulting solution was stirred at room temperature for $5 \mathrm{~h}$. Toluene was removed by rotary evaporation and $\mathrm{H}_{2} \mathrm{O}(100 \mathrm{~mL})$ was added to the residue. The resulting solution was extracted with diethyl ether $(100 \mathrm{~mL} \times 3)$. The organic phase was combined and dried over $\mathrm{Na}_{2} \mathrm{SO}_{4}$, the solvent was removed and the residue was purified by column chromatography (neutral $\mathrm{Al}_{2} \mathrm{O}_{3}$ as stationary phase) using 5-20\% EtOAc/hexane to obtain pure 6 as a yellow liquid (650 mg, 97\% yield). ${ }^{1} \mathrm{H}-\mathrm{NMR}$ $\left(500 \mathrm{MHz}\right.$, Acetone- $\left.d_{6}\right) \delta 7.11(\mathrm{dd}, J=5.2,0.6 \mathrm{~Hz}, 1 \mathrm{H}), 7.09(\mathrm{~d}, J=5.2 \mathrm{~Hz}, 1 \mathrm{H}), 6.16(\mathrm{~d}, J=0.6 \mathrm{~Hz}, 1 \mathrm{H})$, $4.18(\mathrm{~d}, J=2.4 \mathrm{~Hz}, 4 \mathrm{H}), 3.75(\mathrm{t}, J=5.6 \mathrm{~Hz}, 4 \mathrm{H}), 3.49(\mathrm{t}, J=5.6 \mathrm{~Hz}, 4 \mathrm{H}), 3.00(\mathrm{~s}, 6 \mathrm{H}), 2.93(\mathrm{t}, J=2.4 \mathrm{~Hz}$, 2H). ${ }^{13} \mathrm{C}-\mathrm{NMR}\left(126 \mathrm{MHz}\right.$, Acetone- $\left.d_{6}\right) \delta 205.53,160.12,139.58,125.88,120.28,119.63,94.26,80.10,75.36$, 67.20, 58.03, 54.88, 40.36. HRMS-ESI $m / z 252.0540$ ([M + $\mathrm{H}^{+}, \mathrm{C}_{12} \mathrm{H}_{14} \mathrm{NOS}_{2}{ }^{+}$, calc. 252.0511).

S2: Compound 6 (148 mg, $0.4 \mathrm{mmol}$ ) and 3-(4-(dibenzylamino)phenyl)-4-hydroxycyclobut-3-ene-1,2dione $(100 \mathrm{mg}, 0.4 \mathrm{mmol})$ were dissolved in a mixture of 1-butanol $(15 \mathrm{~mL})$ and benzene $(45 \mathrm{~mL})$. The reaction was heated to reflux with Dean-Stark distillation for $2 \mathrm{~h}$. After cooling to room temperature, the solvent was removed and the residue was purified by column chromatography using $0-7 \% \mathrm{MeOH} / \mathrm{CHCl}_{3}$ to obtain pure $\mathbf{S} 2$ as green solid $\left(140 \mathrm{mg}, 58 \%\right.$ yield). ${ }^{1} \mathrm{H}-\mathrm{NMR}(500 \mathrm{MHz}$, $\left.\mathrm{CDCl}_{3}\right) \delta 8.28-8.14(\mathrm{~m}, 3 \mathrm{H}), 7.39-7.27(\mathrm{~m}, 4 \mathrm{H}), 7.25-7.13(\mathrm{~m}, 6 \mathrm{H}), 6.85(\mathrm{~d}, J=8.9 \mathrm{~Hz}, 2 \mathrm{H}), 6.23(\mathrm{~s}, 1 \mathrm{H})$, $4.77(\mathrm{~s}, 4 \mathrm{H}), 4.17(\mathrm{~d}, J=2.4 \mathrm{~Hz}, 2 \mathrm{H}), 3.81(\mathrm{t}, J=4.8 \mathrm{~Hz}, 2 \mathrm{H}), 3.67(\mathrm{~d}, J=6.4 \mathrm{~Hz}, 2 \mathrm{H}), 3.25(\mathrm{~s}, 3 \mathrm{H}), 2.44$ $(\mathrm{t}, J=2.3 \mathrm{~Hz}, 1 \mathrm{H}) \cdot{ }^{13} \mathrm{C}$-NMR: Limited compound solubility prevented ${ }^{13} \mathrm{C}$ analysis. HRMS-ESI $\mathrm{m} / \mathrm{z}$ $602.1704\left([\mathrm{M}]^{+}, \mathrm{C}_{36} \mathrm{H}_{30} \mathrm{~N}_{2} \mathrm{O}_{3} \mathrm{~S}_{2}{ }^{+}\right.$, calc. 602.1698).

S2PEG: Compound S2 (16 mg, $0.026 \mathrm{mmol})$, azido-mPEG 45 (50 mg, $0.024 \mathrm{mmol})$, triethylamine (2 drops) and TBTACu(I)Br $(2 \mathrm{mg})$ was dissolved in $\mathrm{CHCl}_{3}(5 \mathrm{~mL})$ and the reaction mixture was stirred at room temperature for $12 \mathrm{~h}$. After removing the solvent, the residue was purified by column chromatography (silica gel as stationary phase) using $0-10 \% \mathrm{MeOH} / \mathrm{CHCl}_{3}$ to obtain the crude product. The crude product was further purified by a second column (neutral $\mathrm{Al}_{2} \mathrm{O}_{3}$ as stationary phase) using $0-5 \% \mathrm{MeOH} / \mathrm{CHCl}_{3}$ to obtain pure S2PEG as green solid ( $35 \mathrm{mg}$, $55 \%$ yield). ${ }^{1} \mathrm{H}-\mathrm{NMR}$ 
$\left(500 \mathrm{MHz}, \mathrm{CDCl}_{3}\right) \delta 8.23-8.20(\mathrm{~m}, 3 \mathrm{H}), 7.69(\mathrm{~s}, 1 \mathrm{H}), 7.35(\mathrm{dd}, J=8.1,6.6 \mathrm{~Hz}, 4 \mathrm{H}), 7.29(\mathrm{~d}, J=7.3 \mathrm{~Hz}$, $2 \mathrm{H}), 7.23-7.18(\mathrm{~m}, 5 \mathrm{H}), 6.84(\mathrm{~d}, J=9.2 \mathrm{~Hz}, 2 \mathrm{H}), 6.23(\mathrm{~s}, 1 \mathrm{H}), 4.76(\mathrm{~s}, 5 \mathrm{H}), 4.64(\mathrm{~s}, 2 \mathrm{H}), 4.54-4.46(\mathrm{~m}, 3 \mathrm{H})$, 3.84-3.71 (m, 6H), 3.70-3.48 (m, 196H), 3.37 (s, 3H), 3.20 (s, 3H). MS-MALDI (DHBA as matrix) showed a set of peaks around 2421, which reflected the polydispersity of the $\mathrm{PEG}_{45}$ chains.

2-(ethyl(thieno[3,2-b]thiophen-2-yl)amino)ethan-1-ol (7): Compound 4 (1.3 g, $5.8 \mathrm{mmol}), \mathrm{Cu}^{0}$ (70 mg, $1.2 \mathrm{mmol})$, CuI (220 mg, $1.2 \mathrm{mmol})$ and $\mathrm{K}_{3} \mathrm{PO}_{4} \cdot \mathrm{H}_{2} \mathrm{O}(2.7 \mathrm{~g}, 11.6 \mathrm{mmol})$ was suspended in 2-(ethylamino)ethanol $(15 \mathrm{~mL})$. The reaction mixture was stirred at $90{ }^{\circ} \mathrm{C}$ over $5 \mathrm{~h}$. After cooling to room temperature, $\mathrm{H}_{2} \mathrm{O}(80 \mathrm{~mL})$ was added, and the reaction mixture was extracted with diethyl ether $(100 \mathrm{~mL} \times 3)$. The organic phase was combined and dried over $\mathrm{Na}_{2} \mathrm{SO}_{4}$, the solvent was removed and the residue was purified by column chromatography (neutral $\mathrm{Al}_{2} \mathrm{O}_{3}$ as stationary phase) using 10-40\% EtOAc/hexane to obtain pure 7 as light yellow solid (660 mg, 51\% yield). ${ }^{1} \mathrm{H}-\mathrm{NMR}(500 \mathrm{MHz}$, Acetone- $\left.d_{6}\right) \delta 7.10(\mathrm{dd}, J=5.2,0.6 \mathrm{~Hz}, 1 \mathrm{H}), 7.07(\mathrm{~d}, J=5.2 \mathrm{~Hz}, 1 \mathrm{H}), 6.17(\mathrm{~d}, J=0.7 \mathrm{~Hz}, 1 \mathrm{H}), 3.97-3.81(\mathrm{~m}$, $1 \mathrm{H}), 3.76(\mathrm{t}, J=6.1 \mathrm{~Hz}, 2 \mathrm{H}), 3.45-3.35(\mathrm{~m}, 4 \mathrm{H}), 1.19(\mathrm{t}, J=7.1 \mathrm{~Hz}, 3 \mathrm{H}) .{ }^{13} \mathrm{C}-\mathrm{NMR}\left(126 \mathrm{MHz}\right.$, Acetone- $\left.d_{6}\right)$ $\delta$ 205.64, 159.34, 139.55, 120.06, 119.63, 94.31, 59.32, 55.29, 48.45, 29.53, 29.38, 29.22, 29.07, 28.92, 11.67. HRMS-ESI m/z $228.0534\left([\mathrm{M}+\mathrm{H}]^{+}, \mathrm{C}_{10} \mathrm{H}_{14} \mathrm{NOS}_{2}{ }^{+}\right.$, calc. 228.0511).

N-ethyl-N-(2-(prop-2-yn-1-yloxy)ethyl)thieno[3,2-b]thiophen-2-amine (8): Propargyl bromide (900 $\mu \mathrm{L}$, $8.0 \mathrm{mmol})$ was added to a mixture of compound $7(660 \mathrm{mg}, 2.9 \mathrm{mmol})$ in toluene $(15 \mathrm{~mL})$ and $\mathrm{NaOH}$ solution $\left(15 \mathrm{~mL}, 50 \% \mathrm{w} \%\right.$ ). TBA $\mathrm{HSO}_{4}(200 \mathrm{mg})$ as phase transfer reagent was added to the mixture and the resulting solution was stirred at room temperature for $5 \mathrm{~h}$. Toluene was removed by rotary evaporation and $\mathrm{H}_{2} \mathrm{O}(100 \mathrm{~mL})$ was added to the residue. The resulting solution was extracted with diethyl ether $(100 \mathrm{~mL} \times 3)$. Organic phase was combined and dried over $\mathrm{Na}_{2} \mathrm{SO}_{4}$, the solvent was removed and the residue was purified by column chromatography (neutral $\mathrm{Al}_{2} \mathrm{O}_{3}$ as stationary phase) using 5-20\% EtOAc/hexane to obtain pure 8 as a yellow liquid (520 mg, 84\% yield). ${ }^{1} \mathrm{H}-\mathrm{NMR}$ $\left(500 \mathrm{MHz}\right.$, Acetone- $\left.d_{6}\right) \delta 7.11(\mathrm{dd}, J=5.2,0.6 \mathrm{~Hz}, 1 \mathrm{H}), 7.08(\mathrm{~d}, J=5.1 \mathrm{~Hz}, 1 \mathrm{H}), 6.18(\mathrm{~d}, J=0.5 \mathrm{~Hz}, 1 \mathrm{H})$, $4.18(\mathrm{~d}, J=2.4 \mathrm{~Hz}, 4 \mathrm{H}), 3.72(\mathrm{t}, J=5.8 \mathrm{~Hz}, 4 \mathrm{H}), 3.48(\mathrm{t}, J=5.8 \mathrm{~Hz}, 4 \mathrm{H}), 3.39(\mathrm{q}, J=7.1 \mathrm{~Hz}, 4 \mathrm{H}), 2.93$ $(\mathrm{t}, J=2.4 \mathrm{~Hz}, 2 \mathrm{H}), 1.19(\mathrm{t}, J=7.1 \mathrm{~Hz}, 6 \mathrm{H}) .{ }^{13} \mathrm{C}-\mathrm{NMR}\left(126 \mathrm{MHz}\right.$, Acetone- $\left.d_{6}\right) \delta 205.55,159.01,139.54$, $125.67,120.24,119.65,94.55,80.14,75.39,67.45,58.09,52.51,48.43,29.42,29.27,29.12,11.82$. HRMS-ESI $m / z 266.0685\left([\mathrm{M}+\mathrm{H}]^{+}, \mathrm{C}_{13} \mathrm{H}_{16} \mathrm{NOS}_{2}{ }^{+}\right.$, calc. 266.0688).

S3: Compound 8 (150 mg, $0.57 \mathrm{mmol})$, 3,4-dihydroxycyclobut-3-ene-1,2-dione (32 mg, $0.28 \mathrm{mmol}$ ) was dissolved in a mixture of 1-butanol $(15 \mathrm{~mL})$ and benzene $(45 \mathrm{~mL})$. The reaction was heated to reflux with Dean-Stark distillation for $2 \mathrm{~h}$. After cooling to room temperature, the solvent was removed and the residue was purified by recrystallization in $\mathrm{MeOH}$ to obtain pure S3 as a brown solid (158 $\mathrm{mg}, 92 \%$ yield). ${ }^{1} \mathrm{H}-\mathrm{NMR}\left(500 \mathrm{MHz}, \mathrm{CDCl}_{3}\right) \delta 8.11(\mathrm{~s}, 2 \mathrm{H}), 6.19(\mathrm{~s}, 2 \mathrm{H}), 4.18(\mathrm{~d}, J=2.4 \mathrm{~Hz}, 4 \mathrm{H}), 3.81(\mathrm{~d}, J=5.2 \mathrm{~Hz}$, $4 \mathrm{H}), 3.67(\mathrm{~d}, J=5.4 \mathrm{~Hz}, 4 \mathrm{H}), 3.22(\mathrm{~s}, 6 \mathrm{H}), 2.45(\mathrm{t}, J=2.4 \mathrm{~Hz}, 2 \mathrm{H}) .{ }^{13} \mathrm{C}-\mathrm{NMR}$ : Limited compound solubility prevented ${ }^{13} \mathrm{C}$ analysis. HRMS-ESI m/z 608.0921 ([M] ${ }^{+}, \mathrm{C}_{30} \mathrm{H}_{28} \mathrm{~N}_{2} \mathrm{O}_{4} \mathrm{~S}_{4}{ }^{+}$, calc. 608.0932).

S3PEG: Compound S3 (7.0 mg, $0.012 \mathrm{mmol})$, azido- $\mathrm{mPEG}_{45} 3$ (50 mg, $\left.0.024 \mathrm{mmol}\right)$, triethylamine (2 drops) and TBTACu(I)Br (2 mg) were mixed in $\mathrm{CHCl}_{3}(5 \mathrm{~mL})$ and the reaction mixture was sonicated at $40{ }^{\circ} \mathrm{C}$ for $4 \mathrm{~h}$. After removing the solvent, the residue was purified by column chromatography (silica gel as stationary phase) using $0-10 \% \mathrm{MeOH} / \mathrm{CHCl}_{3}$ to obtain the crude product. The crude product was further purified by a send column chromatography (neutral $\mathrm{Al}_{2} \mathrm{O}_{3}$ as stationary phase) using $0-5 \% \mathrm{MeOH} / \mathrm{CHCl}_{3}$ to obtain pure S3PEG as a brown solid (24 $\mathrm{mg}, 42 \%$ yield). ${ }^{1} \mathrm{H}-\mathrm{NMR}$ $\left(500 \mathrm{MHz}_{\mathrm{CDCl}}\right) \delta 8.00(\mathrm{~s}, 2 \mathrm{H}), 7.67(\mathrm{~s}, 2 \mathrm{H}), 6.13(\mathrm{~s}, 2 \mathrm{H}), 4.60(\mathrm{~s}, 4 \mathrm{H}), 4.47(\mathrm{dd}, J=5.5,4.5 \mathrm{~Hz}, 4 \mathrm{H}), 3.79$ $(\mathrm{dd}, J=5.5,4.5 \mathrm{~Hz}, 4 \mathrm{H}), 3.74(\mathrm{~d}, J=5.4 \mathrm{~Hz}, 4 \mathrm{H}), 3.66-3.39(\mathrm{~m}, 429 \mathrm{H}), 3.33(\mathrm{~s}, 6 \mathrm{H}), 1.22(\mathrm{t}, J=7.2 \mathrm{~Hz}, 6 \mathrm{H})$. MS-MALDI (DHBA as matrix) showed a set of peaks around 4391 which reflected the polydispersity of the $\mathrm{PEG}_{45}$ chains. 


\subsection{Association and Kinetic Measurements}

Association Measurements: Stock solutions of squaraine guest, generally $0.03-3 \mu \mathrm{M}$ were prepared and stock solutions of the host $(0.6-60 \mu \mathrm{M})$ were made by using the guest solution as the solvent (to keep the concentration of guest constant during the titration). A solution of guest $(1 \mathrm{~mL})$ was placed in the cuvette and host solution was titrated into guest solution. Spectra changes were recorded by fluorometer after each injection. Association constants were determined using Origin Lab ${ }^{\mathrm{TM}} 8.6$ software (Northampton, MA, USA) that enabled non-linear least squares fitting of the titration data with an equation for 1:1 binding.

Kinetic Measurements: Kinetic studies were performed by using a SFA-20M stopped flow device (empirical dead time $<8 \mathrm{~ms}$ ) (Kyoto, Japan). Equal volumes of host solution and guest solution were mixed by the stopped flow device. The spectral changes were monitored by fluorescence. Second order rates constants were determined using Origin $\mathrm{Lab}^{\mathrm{TM}} 8.6$ software that enabled non-linear least squares fitting of the titration data with an equation for second order kinetics.

\section{Conclusion}

A new family of fluorescent thiophene and thienothiophene-containing squaraine dyes was prepared using simple synthesis and purification methods. Each squaraine can be rapidly encapsulated by a tetralactam macrocycle in organic or aqueous solution. The threaded supramolecular complexes have nanomolar affinity in water, increased stability towards chemical attack by nucleophiles, and favorable optical properties such as increased fluorescence quantum yield and decreased fluorescence quenching upon dye self-aggregation. Together, the set of squaraine dyes and their macrocycle complexes cover the absorption/emission range of $600-800 \mathrm{~nm}$. A notable favorable attribute with the threaded complexes is the capability to excite each of them with $375 \mathrm{~nm}$ light and produce an emission band that is characteristic of the encapsulated squaraine. A wide set of single wavelength and multiplex detection techniques are envisioned using these new dyes for various practical applications in diagnostics, microscopy, molecular imaging, and fluorescence-guided surgery.

Supplementary Materials: The following are available online, Figure S1: (left) Fluorescence (ex: $630 \mathrm{~nm}$, em: $700 \mathrm{~nm}$, slit $3 \mathrm{~nm}$ ) titration isotherm for incremental addition of M2 to a solution of S1PEG (250 nM) in water. (right) Threading kinetic profile generated by mixing equal molar concentration ( $50 \mathrm{nM}$ each) of S1PEG and M2 in a stopped flow device (ex: $630 \mathrm{~nm}$, em: $700 \mathrm{~nm}$, slit $3 \mathrm{~nm}$ ), Figure S2: (left) Fluorescence (ex: 723 nm, em: 753 $\mathrm{nm}$, slit $5 \mathrm{~nm}$ ) titration isotherm for incremental addition of $\mathbf{M} 2$ to a solution of S2PEG (250 nM) in water. (right) Threading kinetic profile generated by mixing equal molar concentration ( $50 \mathrm{nM}$ each) of S2PEG and M2 in a stopped flow device (ex: $723 \mathrm{~nm}$, em: $753 \mathrm{~nm}$, slit $3 \mathrm{~nm}$ ), Figure S3: Photostability of free S1PEG (5 $\mu$ M, left) and M2 $\supset$ S1PEG $\left(5 \mu \mathrm{M}\right.$, right) in $\mathrm{H}_{2} \mathrm{O}$ with continuous irradiation at $550 \mathrm{~nm}$ over $15 \mathrm{~h}$ (fluorescence spectrum was collected every $30 \mathrm{~min})$, Figure S4. Photostability test of free S2PEG (2 $\mu$ M, left) and M2 $\supset$ S3PEG $(2 \mu$ M, right) in $\mathrm{H}_{2} \mathrm{O}$ with continuous irradiation at $650 \mathrm{~nm}$ over $15 \mathrm{~h}$ (fluorescence spectrum was collected every $30 \mathrm{~min}$ ), Figure S5. Photo stability test of the S3PEG $(2 \mu \mathrm{M}$, left $)$ and M2 $\supset \cap$ S3PEG $(2 \mu \mathrm{M}$, right $)$ in $\mathrm{H}_{2} \mathrm{O}$ with continuous irradiation at $750 \mathrm{~nm}$ over $15 \mathrm{~h}$ (fluorescence spectrum was collected every $30 \mathrm{~min}$ ), Figure S6. Chemical stability test of S1PEG and M2 $\supset \cap$ S1PEG. (left) Change in fluorescent maxima band for solutions of (A) M2 $\supset \cap$ S1PEG $(5.0 \mu \mathrm{M})$ or $(\mathrm{B})$ free S1PEG $(5 \mu \mathrm{M})$, in the presence of excess nucleophile $\mathrm{Na}_{2} \mathrm{~S}(5 \mathrm{mM})$ in water at $20^{\circ} \mathrm{C}$. (right) Photograph of samples containing, (A) M2 $\supset \cap$ S1PEG $(80 \mu \mathrm{M})$ or (B) free S1PEG $(80 \mu \mathrm{M})$, after sitting in the presence of excess nucleophile $\mathrm{Na}_{2} \mathrm{~S}(100 \mathrm{mM})$ in water at $20^{\circ} \mathrm{C}$, Figure S7. Chemical stability test of S2PEG and M2 $\supset$ S2PEG by monitoring the change in fluorescent maxima band for solutions of (A) M2 $\supset \cap$ S2PEG $(5.0 \mu \mathrm{M})$ or (B) free S2PEG $(5 \mu \mathrm{M})$ over time in the presence of excess nucleophile $\mathrm{Na}_{2} \mathrm{~S}(5 \mathrm{mM})$ in water at $20^{\circ} \mathrm{C}$, Figure S8. Chemical stability test of S3PEG and M2 $\supset \bigcap$ S3PEG by monitoring change in fluorescent maxima band for solutions of (A) M2 $\supset$ S3PEG $(1.0 \mu \mathrm{M})$ or (B) free S3PEG $(1 \mu \mathrm{M})$, in the presence of excess nucleophile $\mathrm{Na}_{2} \mathrm{~S}(1 \mathrm{mM})$ in water at $20^{\circ} \mathrm{C}$, Table S1. Integrated fluorescent and quantum yield of ICG, S3PEG, and M2 $\supset \cap$ S3PEG in $\mathrm{H}_{2} \mathrm{O}$. Table S2. Photophysical properties of squaraines and their complexes with $\mathbf{M 1}$ in $\mathrm{CHCl}_{3}$.

Author Contributions: W.L. and B.D.S. conceived and designed the study. W.L. and H.H.M. performed the synthesis, characterization and analysis. W.L. and B.D.S wrote the paper. W.L., H.H.M. and B.D.S. edited the paper.

Funding: This research was funded by University of Notre Dame, the NSF (CHE1708240) and the NIH (R01GM059078).

Conflicts of Interest: The authors declare no conflict of interest. 


\section{References}

1. Guo, Z.Q.; Park, S.; Yoon, J.; Shin, I. Recent progress in the development of near-infrared fluorescent probes for bioimaging applications. Chem. Soc. Rev. 2014, 43, 16-29. [CrossRef] [PubMed]

2. Luo, S.; Zhang, E.; Su, Y.; Cheng, T.; Shi, C. A review of NIR dyes in cancer targeting and imaging. Biomaterials 2011, 32, 7127-7138. [CrossRef] [PubMed]

3. Chin, J.; Kim, H.J. Near-infrared fluorescent probes for peptidases. Coord. Chem. Rev. 2018, 354, $169-181$. [CrossRef]

4. Sun, W.; Guo, S.; Hu, C.; Fan, J.; Peng, X. Recent Development of chemosensors based on cyanine platforms. Chem. Rev. 2016, 116, 7768-7817. [CrossRef] [PubMed]

5. Bricks, J.L.; Kachkovskii, A.D.; Slominskii, Y.L.; Gerasov, A.O.; Popov, S.V. Molecular design of near infrared polymethine dyes: A review. Dye Pigment. 2015, 121, 238-255. [CrossRef]

6. Beverina, L.; Salice, P. Squaraine compounds: Tailored design and synthesis towards a variety of material science applications. Eur. J. Org. Chem. 2010, 2010, 1207-1225. [CrossRef]

7. Karpenko, I.A.; Collot, M.; Richert, L.; Valencia, C.; Villa, P.; Mély, Y.; Hibert, M.; Bonnet, D.; Klymchenko, A.S. Fluorogenic squaraine dimers with polarity-sensitive folding as bright far-red probes for background-free bioimaging. J. Am. Chem. Soc. 2015, 137, 405-412. [CrossRef] [PubMed]

8. Maltese, V.; Cospito, S.; Beneduci, A.; De Simone, B.C.; Russo, N.; Chidichimo, G.; Janssen, R.A.J. Electro-optical properties of neutral and radical ion thienosquaraines. Chem. A Eur. J. 2016, 22, 10179-10186. [CrossRef] [PubMed]

9. Stokes, R.J.; Ingram, A.; Gallagher, J.; Armstrong, D.R.; Smith, W.E.; Graham, D. Squaraines as unique reporters for SERRS multiplexing. Chem. Commun. 2008, 567-569. [CrossRef] [PubMed]

10. Shafeekh, K.M.; Soumya, M.S.; Rahim, M.A.; Abraham, A.; Das, S. Synthesis and characterization of near-Infrared absorbing water soluble squaraines and study of their photodynamic effects in DLA live cells. Photochem. Photobiol. 2014, 90, 585-595. [CrossRef] [PubMed]

11. Yum, J.; Walter, P.; Huber, S.; Rentsch, D.; Geiger, T.; Nüesch, F.; De Angelis, F.; Grätzel, M.; Nazeeruddin, M.K. Efficient near-IR sensitization of nanocrystalline $\mathrm{TiO}_{2}$ films by an asymmetrical squaraine dye. J. Am. Chem. Soc. 2007, 129, 10320-10321. [CrossRef] [PubMed]

12. Gassensmith, J.J.; Baumes, J.M.; Smith, B.D. Discovery and early development of squaraine rotaxanes. Chem. Commun. 2009, 6329-6338. [CrossRef] [PubMed]

13. Arunkumar, E.; Forbes, C.C.; Noll, B.C.; Smith, B.D. Squaraine-derived rotaxanes: Sterically protected fluorescent near-IR dyes. J. Am. Chem. Soc. 2005, 127, 3288-3289. [CrossRef] [PubMed]

14. Peck, E.M.; Liu, W.; Spence, G.T.; Shaw, S.K.; Davis, A.P.; Destecroix, H.; Smith, B.D. Rapid macrocycle threading by a fluorescent dye-polymer conjugate in water with nanomolar affinity. J. Am. Chem. Soc. 2015, 137, 8668-8671. [CrossRef] [PubMed]

15. Arunkumar, E.; Fu, N.; Smith, B.D. Squaraine-derived rotaxanes: Highly stable, fluorescent near-IR dyes. Chem. A Eur. J. 2006, 12, 4684-4690. [CrossRef] [PubMed]

16. Gómez-Durán, C.F.A.; Liu, W.; Lourdes, D.; Smith, B.D. Structural control of kinetics for macrocycle threading by fluorescent squaraine dye in water. J. Org. Chem. 2017, 82, 8334-8341. [CrossRef] [PubMed]

17. Liu, W.; Peck, E.M.; Hendzel, K.D.; Smith, B.D. Sensitive structural control of macrocycle threading by a fluorescent squaraine dye flanked by polymer chains. Org. Lett. 2015, 17, 5268-5271. [CrossRef] [PubMed]

18. Johnson, J.R.; Fu, N.; Arunkumar, E.; Leevy, W.M.; Gammon, S.T.; Piwnica-Worms, D.; Smith, B.D. Squaraine rotaxanes: Superior substitutes for $\mathrm{Cy}-5$ in molecular probes for near-infrared Fluorescence cell imaging. Angew. Chem. Int. Ed. 2007, 46, 5528-5531. [CrossRef] [PubMed]

19. Roland, F.M.; Peck, E.M.; Rice, D.R.; Smith, B.D. Preassembled fluorescent multivalent probes for the imaging of anionic membranes. Bioconjugate Chem. 2017, 28, 1093-1101. [CrossRef] [PubMed]

20. Liu, W.; Gómez-Durán, C.F.A.; Smith, B.D. Fluorescent neuraminidase assay based on supramolecular dye capture after enzymatic cleavage. J. Am. Chem. Soc. 2017, 139, 6390-6395. [CrossRef] [PubMed]

21. Shaw, A.S.K.; Liu, W.; Brennan, S.; Smith, B.D.; Shaw, S.K.; Liu, W.; Brennan, S.P.; Betancourt-mendiola, M.D.L.; Smith, D. Non-covalent assembly method that simultaneously endows a liposome surface with targeting ligands, protective PEG chains, and deep-red fluorescence reporter groups. Chem. Eur. J. 2017, 23, 12646-12654. [CrossRef] [PubMed] 
22. Chung, S.-J.; Zheng, S.; Odani, T.; Beverina, L.; Fu, J.; Padilha, L.A.; Biesso, A.; Hales, J.M.; Zhan, X.; Schmidt, K.; et al. Extended squaraine dyes with large two-photon absorption cross-sections. J. Am. Chem. Soc. 2006, 128, 14444-14445. [CrossRef] [PubMed]

23. Meier, H.; Petermann, R.; Gerold, J. Bathochromic or hypsochromic effects via the extension of conjugation: A study of stilbenoid squaraines. Chem. Commun. 1999, 977-978. [CrossRef]

24. Büschel, M.; Ajayaghosh, A.; Arunkumar, E.; Daub, J. Redox-switchable squaraines with extended conjugation. Org. Lett. 2003, 5, 2975-2978. [CrossRef] [PubMed]

25. Meier, H.; Petermann, R. NIR absorbing squaraines by extension of the conjugation with (aminothiazolyl)ethenyl groups. Helv. Chim. Acta 2004, 87, 1109-1118. [CrossRef]

26. Basheer, M.C.; Santhosh, U.; Alex, S.; Thomas, K.G.; Suresh, C.H.; Das, S. Design and synthesis of squaraine based near infrared fluorescent probes. Tetrahedron 2007, 63, 1617-1623. [CrossRef]

27. Bassal, F.; Laurent, A.D.; Le Guennic, B.; Jacquemin, D. Exploring the excited-states of squaraine dyes with TD-DFT, SOS-CIS(D) and ADC(2). Dye Pigment. 2017, 138, 169-175. [CrossRef]

28. Lu, Z.; Twieg, R.J. A mild and practical copper catalyzed amination of halothiophenes. Tetrahedron 2005, 61, 903-918. [CrossRef]

29. Liu, W.; Johnson, A.; Smith, B.D. Guest back-folding: A molecular design strategy that produces a deep-red fluorescent host/guest pair with picomolar affinity in water. J. Am. Chem. Soc. 2018, 140, 3361-3370. [CrossRef] [PubMed]

30. Rurack, K.; Spieles, M. Fluorescence quantum yields of a series of red and near-infrared dyes emitting at 600-1000 nm. Anal. Chem. 2011, 1232-1242. [CrossRef] [PubMed]

31. Nguyen, Q.T.; Tsien, R.Y. Fluorescence-guided surgery with live molecular navigation-A new cutting edge. Nat. Rev. Cancer 2013, 13, 653-662. [CrossRef] [PubMed]

32. Zhang, R.R.; Schroeder, A.B.; Grudzinski, J.J.; Rosenthal, E.L.; Warram, J.M.; Pinchuk, A.N.; Eliceiri, K.W.; Kuo, J.S.; Weichert, J.P. Beyond the margins: Real-time detection of cancer using targeted fluorophores. Nat. Rev. Clin. Oncol. 2017, 14, 347-364. [CrossRef] [PubMed]

33. Gassensmith, J.J.; Arunkumar, E.; Barr, L.; Baumes, J.M.; DiVittorio, K.M.; Johnson, J.R.; Noll, B.C.; Smith, B.D. Self-assembly of fluorescent inclusion complexes in competitive media including the interior of living cells. J. Am. Chem. Soc. 2007, 129, 15054-15059. [CrossRef] [PubMed]

34. Mahou, R.; Wandrey, C. Versatile route to synthesize heterobifunctional poly(ethylene glycol) of variable functionality for subsequent pegylation. Polymers 2012, 4, 561-589. [CrossRef]

Sample Availability: Samples of the compounds S1-S3, S1PEG-S3PEG, M1, and M2 are available from the authors.

(c) 2018 by the authors. Licensee MDPI, Basel, Switzerland. This article is an open access article distributed under the terms and conditions of the Creative Commons Attribution (CC BY) license (http:/ / creativecommons.org/licenses/by/4.0/). 